\title{
Egedy Gergely
}

\section{Nemzet kontra civilizáció? A ,civilizációs államok" felemelkedése}

\section{Nation vs Givilization? The Rise of "Givilizational States"}

\section{Összefoglalás}

A hidegháború befejeződése után a győztes „Nyugat” arra a következtetésre jutott, hogy az általa képviselt értékek univerzális érvényűek, és ez pedig hosszú távra is megalapozza a hegemóniáját. E feltételezést azonban alapjaiban vonta kétségbe - sőt valószínűleg meg is cáfolta - az ún. „civilizációs államok” felemelkedése (azon államoké, amelyek önmagukat nem nemzetállamként, hanem civilizációként határozzák meg és egykori birodalmuk tradícióinak a felélesztésével kísérleteznek.). A tanulmány először a legfontosabb civilizációs államok, Kína, Oroszország, India és Törökország főbb jellemző vonásait kívánja kiemelni, majd rámutat arra, hogy a fentebb említett magabiztos országokkal szemben a „Nyugat” civilizációjának súlyos, a fennmaradását fenyegető belső problémákkal kell szembenéznie. A Szerző következtetése: a „Nyugatnak” nincs más választása, mint hogy lemondjon arról, hogy az értékeit egyetemes érvényűnek tekintse, viszont ezzel együtt minden áron meg kell védenie a saját egyedi kulturális örökségét.

Kulcsszavak: nyugati hegemónia, civilizációs állam, geopolitika, a megtagadás kultúrája.

Prof. Dr. Egedy Gergely, egyetemi tanár, DSc, Nemzeti Közszolgálati Egyetem (egedy.gergely@uni-nke.hu). 


\section{Summary}

After the end of the Cold War, the triumphant West came to the conclusion that the values which it represented were of universal relevance, and this in turn would provide the basis for its long-term hegemony. However, this assumption has been challenged - or even disproven - by the spectacular rise of the so-called „civilizational states”, i.e., states that define themselves not as nation-states but as civilizations, trying to revive the traditions of their erstwhile empires. This study first wishes to explore the main characteristics of the most important civilizational states, China, Russia, India and Turkey, and then it points out that in contrast to these self-conscious countries the civilization of the West has to cope with serious internal problems threatening its existence. The conclusion of the author is that the West has no other choice than to renounce its claims on universalism and at the same time defend by all means its own unique cultural legacy.

Keywords: the hegemony of the West, civilization state, geopolitics, cancel culture

\section{BEVEZETÉS}

Vajon a XXI. században ismét a birodalmak kora jön el? A vesztfáliai béke (1648) után, a polgári fejlődés során a birodalmakat fokozatosan a nemzetállamok váltották fel a nemzetközi politika színpadán. Évszázadunk első negyedében viszont annak lehetünk a szemtanúi, hogy a Nyugat uralta világrend megroppanásával párhuzamosan a nemzetközi kapcsolatok kulcszszereplőivé válnak az egykori birodalmi múltjukat feltámasztani igyekvő, saját civilizációs örökségükre építő államok. A hidegháború megnyerése után a Nyugat sokáig abból indult ki, hogy domináns helyzetét senki sem lesz képes megkérdőjelezni, ám nem így történt. Ellenkezőleg, azt láthatjuk, hogy Kína, India, Oroszország vagy épp Törökország egyre markánsabban és erőteljesebben utasítja el a nyugati típusú demokratikus berendezkedést és piacgazdaságot az egyetemes emberi jogok eszméjével együtt. Sajátos történelmi fejlemény, hogy miközben a Nyugat kivételességének a gondolatát egyre többen kérdőjelezik meg, a fentebb említett államok önmagukat sajátos, egyedi civilizációként határozzák meg. Vajon tud-e a Nyugat e kihívásra választ adni, és mik a hagyományos nemzetállamok esélyei? E kérdés annál is égetőbb, mert a Covid-19 járvány nem csak egészségügyi és gazdasági, hanem civilizációs válságot is hozott az egész világ számára.

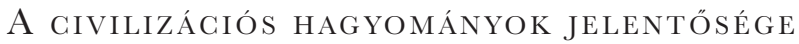

1947 márciusában a neves angol történész, Arnold Toynbee a Time magazin címlapjára került azzal a tézisével, miszerint a marxi történelemfilozófia által középpontba állított osztályoknál fontosabb tényezője a történelemnek a civilizáció. ${ }^{1}$ A szerkesztők ezért a felismeréséért a XX. legbefolyásosabb gondolkodójának nevezték őt. Sajátos módon a civilizációk kulcsszerepét hangsúlyozó gondolat a hidegháború ideológiai csatáiban mégis háttérbe szorult, és Toyn- 
bee-ra még Samuel Huntington (1999) is csak keveset hivatkozott 1996-ban megjelentett „A civilizációk összecsapása" című nagy hatású munkájában.Pedig lett volna rá bőven oka, amint arra Ian Hall (2018) rámutat érdekes tanulmányában, hiszen az alapokat a jeles történész fektette le. A civilizációk drámai mértékben növekvő geopolitikai fontosságát nehéz lenne kétségbe vonni. Joggal írta a 2015-ös párizsi terrorista vérengzéseket követően a neves újságíró, Gideon Rachman (2015), hogy az események ,beszúkitették a teret mindazok számára, akik a 'civilizációk összecsapásának' narratíváját kétségbe akarják vonni”. Huntington koncepciójára az első nagy figyelmet keltő nem-nyugati reflexió a szingapúri Kishore Mahbubani 1998-as munkája volt, amely sarkosan tette fel a kérdést: „Tudnak-e az ázsiaiak gondolkodni?” Aligha véletlen, hogy többen is ,ázsiai Toynbeeként” jellemezték őt.

A világrend átalakulásának talán legfontosabb, s mindenképp szembeötlő tényezője, hogy a nem-nyugati világban folyamatosan növekvo szerephez jutnak az ún. „civilizációs államok”. Mire utalunk e fogalommal? Azon államokra, amelyek nem egy nemzetre, hanem saját civilizációs örökségükre alapozzák legitimitásukat. Ismeretes, hogy Nyugaton az állam legitimációjának nélkülözhetetlen feltétele a demokratikus működés, a civilizációs állam esetében viszont a demokrácia megléte vagy hiánya nem sokat számít: az államtól a civilizáció őrzését várják el, és ennek sikere önmagában biztosítja az állampolgári lojalitást. Ezt úgyis megfogalmazhatjuk, hogy a kultúra itt egyértelműen fontosabb a politikánál; ezek az államok a történelmet használják fel saját legitimálásukra. Több ázsiai szerző szerint is a civilizációs állam megkülönböztető vonása, hogy nem csak politikai hatalommal, hanem rendkívüli morális tekintéllyel is rendelkezik - ebben tér el a nyugati államtípustól.

A civilizációs állam fogalma már egy évtizede megjelent a szakirodalomban. A legújabb és legalaposabb összefoglalást Christopher Coker, a London School of Economics professzora készítette 2019-ben megjelent könyvében (The Rise of the Civilizational State). Ö azt hangsúlyozta, s joggal, hogy a nyugati liberális univerzalizmus háttérbe szorulása a geopolitika tartalmát is alapjaiban alakítja át, a civilizációs törésvonalakat állítva előtérbe. Vagyis a geopolitikában a földrajzi és a politikai elem jelentősége csökken, a kulturális és civilizációs szempontoké viszont nő. Joggal mutat rá Coke, hogy bár a civilizációs államoknak sok eltérő vonásuk van, egy dologban valamennyien egyetértenek, ez pedig a nyugati univerzalizmus elutasítása. És a nyugati kultúrát mindenütt destruktív erőként állítják be: Kínában - nehezen magyarázható módon - az egyházi zene olyan alkotásainak a bemutatását sem engedélyezik, mint Handel Messiásra vagy Verdi Requiemje, Oroszországban pedig a Netflixet is felforgatónak látják (Coke, 2019:170; 177).

2014-es, „Világrend” (World Order) című könyvében Henry Kissinger arra a következtetésre jutott, hogy a civilizációk versengő elképzelései olyan konfliktusokat idézhetnek elő, amelyek a hagyományos államközi küzdelmeknél is veszélyesebbek.

Az új fejleményekre azonban nem csak a történészek és politológusok hívták fel a figyelmet, hanem a messzebbre látó politikusok is. Macron francia elnök például 2019 augusztusában egy - az ország diplomatáinak szokásos évi összejövetele kapcsán tartott - beszédében nagyon világosan kifejtette: Kína, India és Oroszország „,igazi civilizációs államok... amelyek erőteljesen átalakították a politikai világrendet és a vele járó gondolkodásunkat.” (Ambassadors' Conference, 2019). Egy olyan világrendszerhez szoktunk hozzá, hangsúlyozta, amely 
a Nyugat dominanciájára - a 18. században a franciára, a XIX. században a britre, a XX. században pedig az amerikaira - épült, és az új hatalmak jelentőségét sokáig lebecsültük. Ez azonban hiba volt. Tudjuk, hogy a civilizációk el is tudnak süllyedni, folytatta érvelését a francia államfó, és jelenleg ez a veszély Európát is fenyegeti. Nincs tehát más választásunk, mint az alkalmazkodás.

\section{Kína: A Givilizációs Állam klasszikus példáJa}

Kínáról teljes joggal állítható, hogy olyan civilizáció, amely államként kíván fellépni a nemzetközi arénában. Zhang Weiwei, a Fudan Egyetem professzora „A kinai hullám: egy civilizációs állam felemelkedése" (The China Wave: The Rise of a Civilizational State) című, a hazájában 2011-ben megjelent (de a nagy sikerre tekintettel angolul is több kiadást megélt) könyvében büszkén hangsúlyozza, hogy Kína a világ legősibb civilizációját egy minden tekintetben modern állammal ötvözte. Szerinte Kína számára végzetes lenne a nyugati modell átvétele. Az országnak a saját útját kell követnie, ahogyan a reformokat kezdeményező Teng Hsziao-ping óta eddig is tette, és aminek következtében jobb állapotban van, mint valaha is a történelme során. Kína GDP-je 1979-től 2011-ig, a Teng-Hsziao-ping emlékének szentelt könyv első megjelenéséig 18-szorosára nőtt! A szerző kifejti, hogy a nyugati szakértők régóta a kínai rendszer kudarcát jósolják, de nem lett igazuk: a jóslatok omlottak össze, nem Kína. Ebben a narratívában a kínai kultúrának az erős és egységes állam iránti elkötelezettsége hiúsította meg az ország területi szétesését, Tibet vagy az ujgurok lakta Hszincsiang kiválását. Zhang expressis verbis leszögezi: a siker nem egyszerűen egy országé, hanem egy civilizációé. ${ }^{2}$ A civilizációs állam a „fejlődés új modellje”, amely nem követ semmilyen mintát sem, mert saját örökségének egyedi vonásaira épít, s bár képes másoktól tanulni, megőrzi a saját identitását (Zhang, 2011:49-50). Ebből fakadóan nincs szüksége a Nyugat elismerésére sem. Amint „Szun Ce $A$ háború múvészete című munkája sem igényli Clausewitz pecsétjét, amint Konfucius sem igényli Platón jóváhagyását, s a kínai makrogazdasági szabályozás sem az amerikai Federal Reserve Board egyetértését." - olvashatjuk. ${ }^{3}$ Ellenkezőleg, állítja a kínai professzor, Szun Ce könyve hatással lesz a nyugati katonai gondolkodásra, Konfuciustól az egész emberiség tanulhat és a kínai gazdaságpolitika az USA számára is jelentős tanulságokkal szolgálhat. „A kínai hullám” értelmezésében a Nyugattal ellentétben, amely állandóan a haladást és a változásokat keresi, Kína ősei bölcsességére épít, és ennek köszönheti felemelkedését. Ez persze a Nyugaton megszokottól mélyen eltérő gondolkodásmód. A N Nyugat legnagyobb problémája Kínával kapcsolatban az, fejti ki részletesen a brit Martin Jacques, aki már 2009-ben egy bestsellerré vált könyvet írt Kína felemelkedéséről, hogy egyszerűen nem érti meg.

Ebben az örökségben a kulcsszerepet kétségtelenül a konfucianizmus tölti be. Hszi Csinping, a Kínai Kommunista Párt fótitkára számos alkalommal hangsúlyozta a konfuciánus örökség jelentőségét - a Kommunista Párt addigi irányvonalához képest ez mindenképp éles törést jelent. A párt XIX. kongresszusa 2017-ben az egypártrendszerre épülő konfuciánus-leninista modellt „kínai arculatú szocializmusként” határozta meg. A konfucianizmus alapeszméje a társadalmi harmónia - s ez jól illeszkedik a pekingi vezetés törekvéseihez, amelyek a gyors változások közepette is fenn kívánják tartani a belpolitikai stabilitást. A kiugróan gyors 
gazdasági növekedés nagy társadalmi egyenlőtlenségek kialakításával járt, és ezek tompítására a konfucianizmus roppant hasznosnak bizonyult. Hogy a gazdagok és a szegények közötti ellentét példátlan módon kiéleződött, azt még Zhang (2011:9-10) is elismeri és Kína egyik legnagyobb gondjának tartja. A stabilitás mindenek fölött áll - vallotta már Teng Hsziao-ping is, akit Zhang szellemi mesterének tekint. Konfuciust ma már a kínai iskolákban is tanítják, amihez tegyük hozzá, hogy a párt természetesen több lényeges ponton is átértékelte az eredeti konfuciusi tanokat.

Mindezzel összefüggésben Kína az új identitását nem a XIX-XX. századi történelméhez kapcsolja, hiszen az csak megaláztatást hozott a számára, hanem a korábbi évszázadokhoz, amikor birodalomként gondolhatott önmagára.A legélesebb sebet a kínaiak önérzetén a britek által kezdeményezett ún. ópiumháborúk ejtették (Coke, 2019:107). A kritikát Peking a Nyugat „ideológiai globalizmusának” minősíti, s ilyenként utasítja vissza, még azt is állítva, hogy a bírálat hangoztatói az országot ismét félgyarmati státuszba szeretnék visszaszorítani. Sőt, egyes pekingi körökben nem pusztán csak az fogalmazódik meg, hogy Kína egyedi és kivételes ország, hanem az is, hogy morálisan felsőbbrendű a „barbár” külvilággal szemben. E gondolat is ősrégi hagyományra támaszkodik. Ennek része azon állítás is, miszerint Kína nagyhatalomként sem úgy viselkedik, ahogy azok szoktak: semmilyen terjeszkedési szándék sem vezeti (Coke, 2019:118). Ugyanezt állítja Zhang (2011) is, amikor arra utal, hogy a harmónia konfuciusi eszméjét hazája a nemzetközi rendszerre is kiterjeszti: míg a nyugati civilizáció „veszélyes”, a kínai alapvetően békés. A Kínai Külkapcsolatok Egyetemének professzor, Liang Xiajoun (2016) ugyanakkor sokat sejtető módon azt hangsúlyozta, hogy „Kína vezetésre hivatott, de még nem áll készen".

\section{OroszorszÁg Eurázsia Büvöletében}

A mai Oroszország ugyancsak a civilizációs állam jegyeit mutatja. Moszkva olyan civilizációként határozta meg az oroszt, amely se nem nyugati, sem nem keleti, hanem a kettőnek különleges, „eurázsiai” keveréke. Nem újdonság ez az elképzelés sem. Az orosz geopolitikai gondolkodás uralkodó, „eurázsianista” vonala, amelyet többek között Nyikolaj Trubeckoj és Pjotr Szavickij neve fémjelez, már a XX. század első felében abból indult ki, hogy az orosz civilizáció egyesíti Európát és Ázsiát. Vagyis sem Európának, sem Ázsiának nem része, hanem önálló, különleges entitás (Szilágyi, 2019). Az „eurázsianizmus” exponensei tulajdonképpen átvették a „szlavofil” Nyikolajevics Danyilevszkij azon gondolatát, hogy Európa tulajdonképpen nincs is: az pusztán Eurázsia nyugati pereme (Szilágyi, 2019:25-15) Oroszországnak Kínánál sokkal több alapja van arra, hogy „,középső birodalomnak” nevezzék - állítja ez a megközelítés, rámutatva, hogy az Eurázsia törzsét elfoglaló Oroszországot nem lehetséges nemzetállamként értelmezni, csak civilizációként és birodalomként (Szilágyi, 2019:19). Putyin elnök e hagyományra vissza nyúlva hangsúlyozta, hogy országa több egy nemzetállamnál; „multietnikus civilizáció”, amely az elődjének tekintett Bizánchoz hasonlóan keleti és nyugati elemeket egyaránt magába szívott. Putyin nyomatékosan kiemelte, s ez igen figyelemre méltó, hogy a nacionalistáknak is meg kell érteniük: az orosz állam „multietnikus jellegének” kétségbe vonásával „genetikai kódunkat” veszélyeztetik (Valdai International Discussion Club, 
2012). E megközelítésbe illeszkedik azon érvelés is, miszerint, ha Oroszország nemzetállammá válna, megszűnne civilizációnak lenni. (Így Nagy Péter kísérlete, hogy Oroszországból modern nemzetállamot faragjon, kifejezetten káros e nézőpontból.)

A pravoszláv egyháznak megkülönböztetett szerep jutott az orosz civilizációs államban. A moszkvai pátriarka egyenesen „Isten csodájának” nevezte Putyint. Vlagyimir Pasztukov Angliában élő orosz politológus szerint Putyin élesztette fel az orosz messianizmus eszméjét - az orosz kulturális kód alapelemét (Coke, 2012:122). Alekszandr Dugin filozófus, Putyin volt tanácsadója az orosz külpolitikai expanzió ismert ideológusa, akinek mély meggyőződése, hogy Oroszország elképzelhetetlen birodalom nélkül, azt hangsúlyozza, hogy „,az orosz geopolitikát az orosz társadalom jellegzetességeinek alapos megértésével, csak a jelennek és a múltnak az együttes tanulmányozásával lehet vizsgálni”. 4 (Ezt a felfogást képviseli a 2012-ben szerveződött Putyin-barát „eurázsianista” Izborszki Klub is, amely kétségbe vonja az önálló Ukrajna létjogosultságát.) Dugin szerint a Nyugat már elveszítette a hagyományait, értékeket már csak Oroszország őriz. A Nyugattal szembe kell ezért szállni - vagy eltűnünk - állította. Elmondható tehát, hogy az orosz vezetés a Nyugat elutasítását az orosz identitás alkotóelemévé kívánja tenni. ${ }^{5}$ Lev Gudkov orosz kutató a németek felett aratott második világháborús győzelmet már nem egyszerűen a hitleri birodalom feletti diadalként, hanem az egész Nyugat legyőzéseként állította be (Coke, 2012:12). Sok igazság van azonban Roger Cohen véleményében, miszerint míg Kína a „győzelemre esélyes” pozíciójából, addig Oroszország a „vesztes” pozíciójából intéz kihívást a Nyugattal szemben (Coke, 2012:185).

\section{Atatürk eláthozása}

Erdogan Törökországa az ottomán birodalmi múlthoz keresi a visszautat. Ankara látványosan jeleskedik a „civilizációs állam” megteremtésében és az európai civilizációval való szembenállás hangsúlyozásában. A birodalmi múlt felkarolásának jegyében radikálisan elutasítja Kemál Atatürk örökségét, a modern szekuláris török állam megteremtését. A szakítás világszerte ismertté vált szimbolikus gesztusaként az Atatürk által 1934-ben múzeummá nyilvánított isztambuli Hagia Sophia-t mecsetté alakították 2020 júliusában. Minek lehet szimbolikusabb üzenete annál, mint hogy a török egyházi hierarchia feje, Erbas, a Konstantinápoly elfoglalásakor, 1453-ban mecsetté tett templom szószékéről közvetett módon, de félreérthetetlenül átkot mondott Atatürkre? (Zaman, 2020). Kirill moszkvai ortodox pátriárka és Pompeo amerikai külügyminiszter egyaránt kérte, hogy a világörökség részét alkotó 1500 éves épület státuszát ne változtassák meg, de hiába.

Nem meglepő azonban ez a makacsság. Ankara immár a legkevésbé sem igényli, hogy az EU tagjává válhasson - ellenkezőleg, már nem csak zsarolja Európát a migránsok ügyében, hanem fenyegeti is. „Ne három, hanem öt gyereket szüljetek, ti lesztek Európa jövője” - üzente Erdogan a Hollandiában élő törököknek, miután „nácinak” nevezte a hágai kormányt, mert az nem engedélyezte két miniszterének, hogy a török közösség kampányrendezvényén részt vegyenek (Darroch, 2017). Európa véleménye már nem számít: gyarmatosító attitűddel vádolta meg Ankara az EU-t, amiért az megrótta a görög szigetek partjainál kezdett földgáz-kutatásaiért. Erdogan hívei szerint a Nyugatot továbbra is az egykori iszlám-ellenes 


\section{Egedy Gergely: Nemzet kontra civilizáció? A „civilizációs államok” felemelkedése}

keresztes hadjáratok szelleme mozgatja. A török államfó az ENSZ-nek is nekiment, kijelentve, hogy a Biztonsági Tanács tagjai nem sajátíthatják ki a világot (UN Security Council Needs to be Restructured, 2021). Mevlüt Cavosuglu külügyminiszter még tovább lépett, amikor a „,szent háborúk újrakezdődését” helyezte kilátásba (Hurriyet Daily News, 2017).

\section{India: Nehru És Gandhi megtagadása}

A török vezetéshez hasonlóan Narendra Modi kormánya ugyancsak elmarasztalja a modern India megteremtőit, különösen Dzsavaharlal Nehrut, amiért olyan nyugati fogalmakat karoltak fel, mint például a szocializmus, ahelyett, hogy a szubkontinens hindu örökségére építettek volna. De nem szimpatizál Gandhinak, az Indiai Nemzeti Kongresszus egykori legendás vezetőjének a türelmességet hirdető szellemi örökségével sem. A civilizáció előtérbe állításával Modi pártja, az Indiát 2014 óta irányító Bharatíja Dzsanata Párt a hindu nacionalizmus álláspontjára helyezkedett, és régi vetélytársát, a Nemzeti Kongresszust „westernizáló” erőként igyekszik beállítani. E kormányzat alatt az angol típusú demokrácia, amelynek alapelemeit a brit szellemiségű alkotmány is tartalmazza, erősen csorbult. Ennek látványos jele a muzulmán kisebbség diszkriminálása. 2019-ben a választási törvényt úgy módosították, hogy míg a szomszédos országokból (Pakisztán, Banglades, Afganisztán) Indiába menekülő buddhistáknak, szikheknek és keresztényeknek gyorsan indiai állampolgárságot adnak, a muszlimok erre nem számíthatnak (Reuters, 2019). Sokat mondó, hogy India berendezkedésének demokratikus elemei Zhang szemében ugyanakkor nagymértékben felelősek azért, amiért szerinte India jócskán lemaradt Kína mögött (Zhang, 2011:139).

India civilizációja persze ellentmondásosabb képlet, mint Kínáé, hiszen sokféle vallás, sokféle etnikum, sokféle nyelv jellemzi, ám ez nem cáfolja azt, hogy a hinduizmusra építkezve itt is egy minden mástól jól megkülönböztethető, egyedi civilizációt találunk. Octavio Paz (1985), a Nobel-díjas mexikói költő és diplomata, hazája egykori indiai nagykövete elgondolkodtató megjegyzése szerint az indo-európai eredetű India „a Nyugat ellenkező pólusa”, valósággal a „tükörképe”. Paz, aki az 1960-as években dolgozott Delhiben, úgy látta, India nem arra törekszik, hogy alakítsa a történelmet, hanem arra, hogy elkerülje, amennyire lehet. Ma már ezt aligha lehetne elmondani az indiai kormányzatról. Modi már 2014-es megválasztásakor kijelentette, hogy „a 21. század India évszázada lesz”, és azt is jelezte, hogy a hindu civilizáció őreiként számít a világ különböző pontjain élő indiai diaszpórára is.

\section{A Nyugat És a ,Megtagadás kultúráJa”}

Láthatjuk tehát, hogy Eurázsia „civilizációs államainak” nem okoz gondot gyökereik és identitásuk meghatározása, sőt valójában épp ez a legfőbb erőforrásuk. De vajon elmondhatjuk-e ugyanezt a Nyugatról? Aligha.

A Nyugat szemében jelenleg Kína és Oroszország jelenti a legfőbb veszélyt, és a vezetői eközben hajlamosak megfeledkezni arról, hogy a saját civilizációján belül is éles ellentmondások feszülnek. Francis Fukuyama alaposan melléfogott ugyan 1989-ben a liberalizmus világméretű győzelmének a feltevésével, viszont jól ráérzett a nyugati civilizáció belső problémáira. 
Joggal figyelmeztet tehát „A történelem vége” című munkájához később hozzátoldott írásában, „Az utolsó ember”-ben, hogy a nyugati politikai berendezkedés fennmaradásának a dilemmáival többnyire csak a külpolitika síkján foglalkoznak, holott azt a rivális nagyhatalmaknál nem kisebb erejü belső veszélyek is fenyegetik (Fukuyama, 1994:410).

A működési zavarokat markánsan jelzik a Covid-19 járvány kezelésével kapcsolatos kudarcok, de a válságjelenségek körébe illeszthető a 2020. május után kibontakozott „Black Lives Matter" (BLM) mozgalom is. A világszerte elhíresült szobordöntögetések a múltat kívánják a jelentől elválasztani, és ezáltal nyilvánvalóan hadat üzennek a nyugati civilizáció hagyományainak - azoknak, amelyek a világ bármely más civilizációjánál több demokratikus elemet őriznek. A széles tömegtámogatást élvező BLM a neves angol filozófust, John Gray-t leginkább a késő középkor ún. millenarista-messianisztikus szektáira emlékezteti, mert azokhoz hasonlóan az evilági megváltást, a tökéletes társadalmat keresi utópikus és anarchista módon (Gray, 2020). A „társadalmi igazságosság harcosai” (social justice warrior, SJW) meg vannak győződve arról, hogy egy jobb világhoz elég a régit megsemmisíteni - vagyis a nyugati kultúrát elpusztítani. Mozgalmuk Gray szerint a bolsevikokkal is mutat némi párhuzamot, míg azonban az utóbbiaknak határozott céljaik és elképzeléseik, voltak, nekik semmilyen jövőképük nincs. A gondok persze nem új keletűek: számos amerikai egyetemen már régóta a nyugati civilizáció illegitim voltát sulykolják (Egedy, 2016:62-66). „A modern gondolkodás nem gátolja meg, hogy a jövőben nihilista háborút indítsanak a liberális demokrácia ellen, és éppen a saját édes gyermekei” - írja Fukuyama (1994:471). Jelenleg ott tartunk, hogy a BLM „öntudatra ébredt” hívei már kötelező normává tennék a nyilvános bocsánatkérést a nyugati civilizáció melletti kiállásért.

A mai nyugati civilizáció legsúlyosabb problémája tehát az önmagával való meghasonlás - a nemrég elhunyt Roger Scruton (2005) ezt, találóan, a „megtagadás kultúrájaként” (cancel culture) határozta meg. Míg a „nem-nyugati” világban a civilizációs örökség feltárására és középpontba állítására törekednek, Nyugaton az az elvárás érvényesül, hogy tagadjuk meg a bennünket másoktól megkülönböztető hagyományokat. Mintha a Nyugat feláldozná a saját civilizációját egy olyan univerzalizmus kedvéért, amely rajta kívül senkinek sem kell... Ez az attitűd természetesen alaposan meggyengíti civilizációnk ellenálló képességét egy olyan korszakban, amikor erre nagyobb szükség lenne, mint valaha. Elkerülhetetlen tehát az irányváltás: a Nyugatnak a saját örökségére kell támaszkodnia, s le kell mondani arról, hogy a világot a saját képére formálja. El kell fogadnia, hogy a civilizációja rendkívül gazdag, de nem egyetemes.

\section{A GivilizÁció, MINT a Nemzet ALTERnATívÁJA?}

Megalapozottan mondta Macron már idézett beszédében, hogy a civilizációs államoknak sokkal nagyobb kezdeményezőkészségük van a régi európai államoknál. Az Indiát irányító Dzsanata Párt főtitkára úgy nyilatkozott, hogy „mostantól fogva Ázsia fogja irányítani a világot s ez mindent megváltoztat, mert itt nekünk civilizációink, nem pedig nemzeteink vannak". ${ }^{6}$ Ez bizonyára kulcsmondat: paradox módon a civilizációkat állítja a Nyugattal asszociált nemzetekkel szembe. Ez már csak azért is figyelemre méltó, mert a civilizáció eszméjét a 


\section{Egedy Gergely: Nemzet kontra civilizáció? A „civilizációs államok” felemelkedése}

XVIII. századi Európa dolgozta ki, s ezzel összefüggésben nem alaptalanul vélte úgy a nagy francia történész, Fernand Braudel, hogy a civilizációk többes számú használata az egyes számban használt civilizáció elvetését jelentheti. A nemzetállam mint politikai forma történelmileg valóban a nyugati civilizációhoz kötődik, hiszen igazi nemzetek csak e körben alakultak ki. Joggal vethető fel, hogy vajon a civilizációra való hivatkozás nem a nacionalizmus egy sajátos burkolt formája-e. A kenti egyetemen tanító Adrian Pabst (2019) mindenesetre úgy fogalmaz, hogy ezek az államok egy sajátos hibrid doktrínát képviselnek: otthon a nacionalizmust, a nemzetközi arénában pedig civilizációjuk hangsúlyozását és védelmét. Tegyük ehhez hozzá, hogy a civilizációs államok offenzív fellépése nyilvánvalóan megkérdőjelezi a hagyományos nemzetállamoknak a nemzetközi rendszerben betöltött pozícióját.

A két elmúlt évszázad a nemzetállamé volt; vajon a mostani a civilizációs államoké lesz? Mint ismeretes, a mai nemzetállamok több kihívással is kénytelenek szembe nézni: egyrészt a nagy szupranacionális integrációk részéről, másrészt pedig a birodalmi keretekben gondolkodó államok részéről. Megalapozottan vethető fel, hogy vajon az EU maga is nem egy „civilizációs állammá” válás útján halad-e... (Zhang azt írja „A kínai hullám-ban, hogy „ha a régi római birodalom egyben maradt volna, és modern állammá vált volna, Európa mára egy közepes méretű civilizációs állammá vált volna.”). Igaza van természetesen Scrutonnak (2005:170-173) abban, hogy a nemzetállam nem a társadalmi tagság egyetlen lehetséges forrása, ám az is kétségtelen, hogy - minden hibájával együtt - a zsidó-keresztény civilizációs örökségünkkel ez áll a legszervesebb kapcsolatban, s ez nyújtja a közösség olyan mintáit, amelyek a személy méltóságát a leginkább biztosítani tudják. Van tehát okunk arra, hogy megvédjük a nemzeteket fenntartó nyugati civilizációt, s ezzel magyarságunkat is.

\section{JEGYZETEK}

1 Arnold J. Toynbee, 17 March, Time (TIME Magazine Cover) http://content.time.com/time/covers/0,16641,19470317,00.html Letöltés: 2021 okt. 29.

2 A kínai civilizációs állam fejlődését a „A kínai hullám” 3. fejezete részletesen végig kíséri. Zhang: i.m. 47-82.

3 Zhang: i.m. 3. (A FED az USA-nak a központi jegybanki funkciót betöltő intézménye)

4 Dugint idézi: Szilágyi: i.m. 25. Dugin talán legfontosabb munkája „A geopolitika alapjai” címet viseli, és először 1997-ben jelent meg. Magyarul is elérhető tőle: A negyedik politikai eszme, Kvintesszencia Kiadó, Debrecen, 2017.

5 Tegyük ugyanakkor hozzá, hogy az oroszok számára ezzel együtt a Nyugat nem olyan távoli és idegen, mint Kína számára - ez magyarázza, hogy mindig is számottevő ereje volt az ún. „nyugatos” hagyománynak is.

6 Idézi: Macaes, Bruno: The Attack of the Civilization-State, Noema, June 15 2020, https://www.noemamag. com/the-attack-of-the-civilization-state/. Letöltés: 2021 okt. 29.

\section{FELHASZNÁLT IRODALOM}

Coke, C. (2019): The Rise of the Civilizational State, Polity Press, Cambridge

Darroch, G. (2017): Netherlands „will pay the price” for blocking Turkish visit-Erdogan, The Guardian, 12 March, 2017, https://www.theguardian.com/world/2017/mar/12/netherlands-will-pay-the-price-for-blocking-turkish-visiterdogan

Egedy Gergely (2016): Az Egyesült Államok kulturális identitása, in: Pogrányi Lovas Miklós (szerk.) Konzervatív rene- 
szánsz az Egyesült Államokban, Századvég, 2016

Gray, J. (2020): The woke have no vision of the future, Unherd, June 17, 2020, https://unherd.com/2020/06/thewoke-have-no-vision-of-the-future/.

Fukuyama, F. (1994): A történelem vége és az utolsó ember, ford. Somogyi Pál László, Európa, 1994.

Hall, I. (2018): Clashing Civilizations: a Tonybeean Response to Huntington, https://www.e-ir.info/2018/04/18/clashing-civilizations-a-toynbeean-response-to-huntington/.

Huntington, S. P. (1999): A civilizációk összecsapása és a világrend átalakulása, Európa

Jacques, M. (2009): When China Rules the World. The End of the Western World and the Birth of a New Global Order, Allen Lane, London, 2009

Kissinger, H. (2014): World Order, Allen Lane, London

Liang X. (2016): Chine is destined to lead, but not ready, EastAsia Forum, 13 September, 2016, https://www.eastasiaforum.org/2016/09/13/china-is-destined-to-lead-but-not-ready/

Macron, E. (2019): Ambassadors' Conference. https://lv.ambafrance.org/Ambassadors-conference-Speech-by-M-Emmanuel-Macron-President-of-the-Republic

Mahbubani, K. (1998): Can Asians Think?, Understanding the Divide Between East and West, Times Media Public Limited, Singapore

Macaes, B. (2020): The Attack of the Civilization-State, Noema, June 15 2020, https://www.noemamag.com/the-attack-of-the-civilization-state/.

Pabst, A. (2019): China, Russia and the return of the civilisational state, New Statesman, 8 May, 2019, https://www. newstatesman.com/world/2019/05/china-russia-and-the-return-of-the-civilisational-state.

Putin (2013): Putin at the meeting of the Valdai International Discussion Club, September 20.https://russialist.org/ transcript-putin-at-meeting-of-the-valdai-international-discussion-club-partial-transcript/

Paz, O. (1985): One Earth, Four or Five Worlds: Reflections on Contemporary History, Carcanet, London, 1985

Rachman, G. (2015): Do Paris Terror Attacks Highlight a Clash of Civilizations?, Financial Times, 16 November 2015, https://www.ft.com/content/96b9ed08-8c46-1 1e5-a549-b89aldfede9b.

Reuters (2019): The New Indian Citizenship Law „discriminatory” against Muslims:UN, Reuters, 13 December 2019, https://www.reuters.com/article/us-india-citizens-un-idUSKBN1YH145.

Scruton, R. (2005): A Nyugat és a többi, in: Roger Scruton: A nemzetek szükségessége, ford. Pásztor Péter, Helikon

Szilágyi István (2019): Az orosz geopolitikai gondolkodás. Áttekintés, Geopolitikai Szemle, I. évf., 2019/1

Turkish FM warns of „religion wars” in Europe in remarks on Dutch elections, Hurriyet Daily Neres, March 162017, https://www.hurriyetdailynews.com/turkish-fm-warns-of-religion-wars-in-europe-in-remarks-on-dutch-elections---1 110874

UN Security Council Needs to be Restructured (2021): Erdogan, 22.09. 2021, https://www.aa.com.tr/en/turkey/ un-security-council-needs-to-be-restructured-erdogan/1981988

Zaman, A. (2020): Istanbul's Hagia Sophia holds first Friday prayers since reconversion to mosque, Al-Monitor, July 24, 2020, https://www.al-monitor.com/originals/2020/07/turkey-hagia-sophia-muslim-prayers-mosque-controversy.html

Zhang W. (2011): The China Wave: Rise of a Civilizational State, World Century Publishing Corporation, Hackensack, (Angol megjelenés éve: 2012) 